\title{
Hobbes, Calvinism, and Determinism
}

\author{
Book or Report Section
}

Accepted Version

Cromartie, A. (2018) Hobbes, Calvinism, and Determinism. In: van Apeldoorn, L. and Douglass, R. (eds.) Hobbes on Politics and Religion. Oxford University Press, Oxford. ISBN 9780198803409 Available at http://centaur.reading.ac.uk/69963/

It is advisable to refer to the publisher's version if you intend to cite from the work. See Guidance on citing.

Publisher: Oxford University Press

All outputs in CentAUR are protected by Intellectual Property Rights law, including copyright law. Copyright and IPR is retained by the creators or other copyright holders. Terms and conditions for use of this material are defined in the End User Agreement.

www.reading.ac.uk/centaur 


\section{CentAUR}

Central Archive at the University of Reading

Reading's research outputs online 
Hobbes, Calvinism, and Determinism

Hobbes's lifetime coincided with two different revolutions. ${ }^{1}$ The first, of which he disapproved, changed England's parliament from an occasional event into an institution through which the monarch was obliged to govern. The second transformed its religion. An Englishman of Hobbes's generation - that is, somebody whose formal education took place in the two decades either side of 1600 - could assume that the country's religion was securely Protestant and that its Protestantism was in essence Calvinist. In spite of its episcopalian institutional structure and the residual ceremonies of its liturgy, the Church of England shared its basic teachings about faith, grace, and human agency with its own internal critics, the English puritans and the Reformed (as opposed to the Lutheran) churches: the country was 'doctrinally a part of Calvinist Europe'. ${ }^{2}$ Among other things, this meant that English theologians virtually all subscribed to a consensus that God had quite gratuitously predestined His elect without the slightest reference to any fact about them; more liberal-minded theories to the effect that this divine election was in some way contingent on His foresight of their faith were usually then known as 'Lutheran'. ${ }^{3}$

In the course of the next generation, this consensus was abandoned. In 1622, King James promulgated 'Directions for Preachers' by which the Church's ministers (below the rank of Dean) were prohibited from dealing with predestinarian topics, ${ }^{4}$ from 1628 onwards, disputation on such questions was a serious offence even in strictly academic settings. ${ }^{5}$ Although these interventions were officially presented as even-handed in their character, they had the effect of transforming Calvinist theories of predestination from an unquestioned national orthodoxy into (at most) an intellectual option. In the absence of state support and university instruction, the more commonsensical 'Lutheran' views (now generally referred to as being 'Arminian') had an understandable tendency to triumph by default. Moreover, the upheavals of the English revolution considerably hastened this established tendency. The

\footnotetext{
1 I am grateful to the editors and Al Martinich for comments upon an earlier draft of this essay.

$2 \quad$ Nicholas Tyacke, 'Puritanism, Calvinism, and counter-revolution' in Conrad Russell (ed.), The origins of the English revolution (London: Macmillan, 1973), pp.128-3.

3 Tyacke, 'Puritanism, Calvinism, and counter-revolution', 130.

4 Nicholas Tyacke, Anti-Calvinists: the rise of English Arminianism c.1590-1640

(Oxford: Clarendon, 1987), pp.102-3.

$5 \quad$ Heylyn, Cyprianus Anglicus (1668), p.189.
} 
real or imagined excesses of antinomians encouraged a new suspicion of a theology that seemed to sever grace from normal standards of behaviour. The upshot, in some quarters, was a new understanding of Christianity that emphasised ethical teachings that were, at least in principle, accessible to reason at the expense of dogma and of the sacraments.

On most theological questions, Hobbes looks like a supporter of this shift in attitudes. Martinich himself notes affinities with William Chillingworth, ${ }^{6}$ a liberal theologian suspected of Socinianism by most Calvinists. ${ }^{7}$ But even in questions bordering upon predestination, Hobbes's apparent sympathies were with the modernisers. At the heart of Calvinism as mainstream theologians understood it was a theology of imputation insisting that 'justification' - the pivotal transition that makes the fallen soul regenerate - is God's response to Christ's works as imputed to the sinner. ${ }^{8}$ In each of his three great political works, Hobbes treated 'justification' as God's response to human 'faith and justice (meaning still by justice, not absence of guilt, but the good intentions of the mind, which is called righteousness by God, that taketh the will for the deed)'. ${ }^{9}$ In The Elements, he took it that the biblical texts where 'works' are criticised were actually directed against 'external' works, but 'if the will be taken for the deed, or internal for external righteousness, then do works contribute to salvation. ${ }^{10}$ The more this view is scrutinised, the less Calvinistic it seems. Most Calvinists admittedly defended their position by stressing that faith is in practice inseparable from works: 'justification' was the start of the process of 'sanctification' by which a vivifying faith expressed itself in action. But the Hobbesian view inverted this whole process: all three of his discussions of the subject imply that the will to act justly is an achievement prior to the faith that brings salvation. Good intentions set the sinner 'in an estate or capacity of salvation, whensoever he shall have faith.' ${ }^{11}$ An unwise flourish in Leviathan ignores a fundamental Reformation shibboleth by suggesting - with the Catholics - that there exists a

6 Martinich, Two Gods, 214-15, 216-17

7 Chillingworth's reputation was founded on one book - The religion of Protestants (1638) - on which see Francis Cheynell, The rise, growth and danger of Socinianism (1643), esp. p.28. Cheynell believed that Chillingworth's 'Arminian principles' were 'manifest to anyone that hath but peeped into [his] book' (p.35).

$8 \quad$ The technical points at issue are well explained in C.F.Allison's classic The rise of moralism: the proclamation of the Gospel from Hooker to Baxter (1966).

$9 \quad$ El., II vi 10; De Cive, xviii 12; Leviathan, 950.

$10 \quad E l$. , II vi 10.

11 El., II vi 10. Cf. De Cive, xviii 12; Lev., 950. 
sense in which a fallen human being can 'merit' his salvation ${ }^{12}$ (thus rejecting, among other authorities, the Church of England's Article XI: 'we are accounted righteous before God, only for the merit of our Lord and Saviour Jesus Christ by Faith, and not for our own works and deservings').

Underlying this essentially unProtestant position was an utterly unCalvinistic anthropology. All Calvinists believe in 'original or birth-sin' (to use the expression adopted in the heading to Article IX). Hobbes acknowledged that the Bible states that human beings are evil, but insisted that it 'cannot be conceded without impiety that men are evil by nature', if 'by nature' means 'from birth itself (ab ipsa nativitate)'. ${ }^{13}$ It is impossible to reconcile his view of human passions as essentially innocent with the much more severe official doctrine that 'concupiscence and lust hath have in themselves the nature of sin' (Article IX) and even that 'we do not doubt but [works done before justification] have the nature of sin' (Article XIII). As the eighteenth-century Calvinist John Gill was to complain, in the context of a catalogue of such divergences, 'it is notorious, that in many things there is a plain and manifest agreement between him and the Socinians and Arminians'. ${ }^{14}$

It is hardly too much to say, then, that the only area in which Hobbesian theology concurred with Calvinism was over the complex question of the relationship between 'free will' and God's omnipotence. In the debate about free will conducted with John Bramhall, Hobbes went out of his way to identify his own determinism with the positions defended by traditional Protestants, especially their insistence that 'liberty' can be consistent with 'necessity'. He advanced the arresting thesis that 'free will' was unknown to the ancients, who recognised only 'necessity' and 'chance', while St Paul

deriveth all actions from the irresistible Will of God, and nothing from the will of him that runneth or willeth. But for some ages past, the Doctors of the Roman Church have exempted from this dominion of Gods Will, the Will of Man; and brought in a Doctrine that not onely Man, but also his Will is Free, and determined to this or that action, not by the Will of God, nor necessary causes, but by the power of the Will it Self. And though by the reformed Churches instructed by Luther, Calvin and others, this opinion was cast out, yet not many

12 The problem is the use of word 'merit'; in what seems to be a tacit omission of error, it is omitted from the Latin version. Leviathan, II, 208. For another view, see Martinich, Two Gods, 239-42.

13 De Cive, Praefatio 12.

14 John Gill, The cause of God and truth, 4 vols (1737), vol.III, p.181 
years since it began again to be reduced by Arminius and his followers and became the readiest way to Ecclesiastical promotion... ${ }^{15}$

It was in this specialised context that he made the startling claim that though he despised such writers as Suarez and Duns Scotus, 'other Doctors of the Church (as Martin Luther, Philip Melancthon, John Calvin, William Perkins, and others) that did write their sense clearly, I never sleighted, but alwayes very much reverenced, and admired. ${ }^{16}$

Those biographically-minded scholars who have been willing to accept such statements at face value have recently had a choice of two approaches. Al Martinich's straightforward and lucidly-argued position has been that Hobbes was loyal to 'English Calvinism', at least if 'Calvinism' is narrowly defined as a belief about predestination. On this view, 'Calvinism' was a personal commitment: 'Hobbes is especially committed to the thought of Calvin and of Puritan theologians such as William Perkins. Hobbes's determinism...is not merely a part of his mechanistic materialism; it is logically tied to Calvin's doctrines of predestination and belief in the omnipotence of God.' ${ }^{17}$ Though Calvinists might well believe 'in the ability to act from some internal principle such as the soul', they were, however, deterministic with respect to God: they did not believe that 'a human being could initiate an action that does not have God as its ultimate source'. ${ }^{18}$ The necessity God imposes on all actions was thus seen as compatible with a weak sense of freedom. Jürgen Overhoff, by contrast, sees the determinism as wholly secular. Hobbes may of course have been sincere in appealing to the major sixteenth-century Reformers, but he did so only relatively late in his career and their theology functioned as a means of defending some doctrines that he adopted for quite different reasons. In Overhoff's view, the 'mechanistic-materialist' character of Hobbes's thinking in fact casts a degree of doubt on his sincerity, but 'judged by the...epistemic standards of his contemporaries, Hobbes's theological doctrine of the freedom of the will

15 Thomas Hobbes, The questions concerning liberty, necessity, and chance (1656), pp.1-2.

Thomas Hobbes, Questions, 212.

17 A.P.Martinich, The two Gods of Leviathan (Cambridge, 192), p.3. See also p.273.

18 A.P.Martinich, 'On Hobbes's English Calvinism: necessity, omnipotence, and goodness', 24-5. 
was... a recognizable and, above all, credible seventeenth century theological defense of his scientific determinism.' 19

On both views, Hobbesian determinism could reasonably draw support from Calvinistic thinking, and Hobbes's stance in his debate with Bramhall could reasonably be taken for a Calvinist position. As we shall see, however, both views face serious problems. Noel Malcolm long ago remarked that 'the more thoroughly one supposes [Hobbes] to have been grounded in the principles of Calvinism, the more likely it seems that he would have recognised the fact that Calvinists regarded divine Providence as utterly different from causal determination.' $^{20}$ This chapter documents the truth of Malcolm's observation by showing, first, that Calvinists were not determinist and, secondly, that Hobbes revealed a striking ignorance of fairly basic features of their theology. But it also raises further, perhaps more important, questions about the motivation of his philosophy.

During the sixteenth century, mainstream Western theology was Augustinian; both Protestants and Catholics thought it important to present their theories about grace as being compatible with St Augustine's. But Augustine's views notoriously required him to give an account of 'liberty' in two quite different contexts. His early work De libero arbitrio voluntatis - 'on the free choice of the will' - begins with the question 'Please tell me whether God is not the author of evil?' 21 The point of the idea of liberum arbitrium was to locate the origin of evil in creation in such a way as to avoid the Manichaean error of making evil equal and opposite to God and the fatalistic error of making God responsible for every evil action. By the end of his life, however, he was increasingly preoccupied with his polemical battles against Pelagians: heretics who objectionably maintained that the divine election of certain human beings to salvation was contingent upon something that those human beings did. His

19 Jürgen Overhoff, Hobbes's theory of the will (Lanham, MD, 2000), p.160. For a similar view, see Leopold Damrosch, Jr,, 'Hobbes as Reformation theologian: implications of the free-will controversy', pp.339-52.

20 N.R.Malcolm, 'Thomas Hobbes and voluntarist theology', Cambridge PhD thesis (1982), p.204n.

21 Augustine, On the free choice of the will, On grace and free choice, and other writings, ed.Peter King (Cambridge: Cambridge UP, 2010), p.3. 
theory of evil thus involved him in picking out a moment of free choice as a locus of evil; his anti-Pelagian polemics required him to deny that it was possible to use that freedom in such a way as to deserve salvation.

The debate of which Hobbes claimed a knowledge was Augustinian in that all (except perhaps the first) of its participants believed that their positions were non-determinist. It began in 1520, when Martin Luther provocatively endorsed John Wycliffe's thesis that every human action is 'absolutely necessary'. This rash statement gave an opening to Erasmus, who made it the occasion of his attack on Luther: De libero arbitrio diatribe (1523). Luther's intensely-felt reply, De servo arbitrio (1525), could not be said to shy away from polemical over-statement, but nonetheless remained within Augustine's paradigm. He noted (which may have struck Hobbes) that secular philosophy has not yet finally settled whether anything can set itself in motion. ${ }^{22}$ There is, however, evidence that his own view of the matter was libertarian: 'for we are not discussing being by nature, but being by grace (to put it in current terms). We know there are things liberum arbitrium does by nature, such as eating, drinking, begetting, ruling'. ${ }^{23}$ Five years later, the eighteenth article of the Confession of Augsburg (1530) was to settle the point by pronouncing that 'they teach that the human will has some liberty to bring about civil justice and choose things subjected to reason.'

If a determinist is somebody who thinks that human actions are externally determined (by God or by nature) in exactly the same way as other physical events, Luther was not, then, a determinist. So far from seeing the bondage of the will as an instantiation of deterministic order, he saw it as a way that postlapsarian human beings were limited in certain spheres of their activities. It was intelligible to say that that we are 'free' in ordinary secular concerns in a way that we are not free in those areas of life that have a direct bearing on our chances of salvation, and also (which in his view amounts to the same thing) that 'liberum arbitrium avails only for sinning'. ${ }^{24}$ It may be thought that his position was nonetheless 'deterministic' with respect to God, on the grounds (to take a characteristic statement) that 'man apart from

22 Luther, De servo arbitrio, ed.Philip S.Watson, in Luther and Erasmus: free will and salvation, (SCM, 1969), p.173.

$23 \quad$ Luther and Erasmus, 286.

$24 \quad$ Luther and Erasmus, 287. 
the face of God remains nonetheless under the general omnipotence of God, who does, moves, and carries along all things in a necessary and infallible course. ${ }^{25}$

No one would seriously dispute the existence of such statements. Equally, no one would dispute that Luther believed that rational theodicy was futile. He did not appeal solely to God's omnipotence to justify the existence of evil in the world: we can be sure that God has a good reason both for permitting evil to exist and also for inscrutably deciding not to elect the vast majority of human beings. But the answer is concealed from fallen creatures. ${ }^{26}$ in any case, he was loyal to the unvarnished text: the plain sense of the Bible was not to be subverted by scholastic subtleties (with an entertaining impudence Hobbes would have found amusing, scholastics were referred to as 'sophistae'). It is clear that God wills everything that happens. It is not for human beings to evade this plain biblical truth by distinguishing absolute necessity - necessitas consequentis - from a merely hypothetical necessitas consequentiae. ${ }^{27}$ When scripture pronounced that God 'hardened' Pharoah's heart, the hardening should be taken at face value: God acted on the tyrant's will to cause him to do evil. $^{28}$

It is, however, worth noting that these points are not decisive: precisely because they flow from a suspicion of human reason, they offer wide scope for acceptance of the nonHobbesian view that the relationship between necessity and freedom is something ultimately mysterious (there is, to be sure, some mystery in the Hobbesian position, but it is located elsewhere: in the nature of God) It is also well worth noting that Luther can be read as having a traditional Augustinian position: he certainly did not doubt the Augustinian principle that evil is located in the wills on which God acts, rather than in the motion by which he acts upon them ${ }^{29}$ nothing he says is inconsistent with Augustine's view that evil had its origins in Adam's (and the Devil's) misuse of their freedom.

25 Luther and Erasmus, 287. A good exposition of this kind of view is Overhoff, Theory of the will, 146-7.

$26 \quad$ Luther and Erasmus, 331-2.

27 Luther and Erasmus, 120-22.

$28 \quad$ Luther and Erasmus, 237.

$29 \quad$ Luther and Erasmus, 235-6. 
If Hobbes ever seriously studied De servo arbitrio, he surely found material that he could sympathise with, mixed up with other material (about 'merit, for example) ( $^{30}$ to which he was at best indifferent. It should, however, be noted that his appeal was not to this extraordinary text, but to a tradition that ran from Luther to Perkins. As we shall see, the clear trajectory of this tradition was in a libertarian direction. The first step, Calvin's thought, resembles Luther's in its reluctance to explain away the plain sense of the scriptural revelation; like Luther, he insisted that 'hardening' meant what it said. ${ }^{31}$ He claimed that he was loyal to the substance of Augustine, but thought that the expression liberum arbitrium encouraged dangerous misunderstandings. ${ }^{32}$ But his most revealing statements, for present purposes, are not found in the Institutes (the great theological text-book that everyone learned had read), but in the debate he conducted with the Catholic polemicist Albertus Pighius. Pighius taxed the Lutherans with inconsistency on the grounds that 'they [now] attribute some liberty to the human will in those things which belong to civil justice and concern the outward face of things. 33

Calvin's reply to this was interesting: he flatly denied the existence of inconsistency, while admitting that the later formulations had had the effect of altering the doctrine's exposition. He added that

[Melancthon in his capacity as principal author of the Confession of Augsburg] desired to linger only on that teaching which alone is peculiar to the church and necessary to know for salvation, namely, that natural powers by themselves have no ability to conceive faith, to obey divine law, and to attain entire spiritual righteousness. What they can do in external affairs he did not want to discuss in too much detail, because it is of no importance to the faith. ${ }^{34}$

His central point here is illuminating: the earliest Reformers were committed missionaries whose over-riding purpose was to rescue threatened souls. Even if they had in fact believed that God controls the world in a deterministic fashion, they had no religious reason to emphasise the fact. Calvin is also helpful in carefully distinguishing two different concerns that press towards determinism with respect to God. The subject of freedom is tackled in two different contexts in the Institutes: not only in the famous treatment of predestination, but

\footnotetext{
30 Luther and Erasmus, 208-15

31 John Calvin, Institutes of the Christian religion (1559), 1.18.2, 2.4.3-4.

$32 \quad$ Institutes, 2.2.8.

33 Albertus Pighius, De libero hominis arbitrio et divina gratia (Cologne, 1542), fo.6v.

34 John Calvin, The bondage and liberation of the will, ed.A.N.S.Lane, tr.G.I.Davies
}

(Grand Rapids, MI, 1996), p.29. 
also in the chapter about God's providence. In a passage of the latter that was to be appealed to by John Bramhall, he actually presupposed that human beings are free, while emphasising God's control through special providence. As Bramhall acutely remarked,

Calvine, who is the least disfavourable to [Hobbes of six authorities that Hobbes had cited], saith no more but this, Deum quoties viam facere vult suae providentiae, etiam in rebus externis hominum voluntates flectere \& versare, nec ita liberam esse ipsorum electionem, quin eius libertati Dei arbitrium dominetur. That God (not allwayes but) as often as he will make way for his providence, doth bow and turn the wills of men, neither is their election so free but that the good pleasure of God hath a dominion over their liberty.

It followed that 'Calvine did know no universall determination of all externall acts by God, but onely in some extraordinary cases. 35 This seems exactly right. Nobody who reads Calvin can fail to note his interest in special divine interventions. Not surprisingly, he was loyal to Augustine in wishing to stop short of 'Stoicism': 'Good luck to the Stoics with their fate', as he told Pighius, 'let the free will of God be for us the controller (moderatrix) of all things. But it seems absurd that contingency should be taken from the world. ${ }^{36}$ Unlike Luther, he accepted the distinction between necessitas consequentiae and necessitas consequentis. ${ }^{37}$

Thereafter, the development of Calvinist belief was in a generally libertarian direction. It was common ground that Adam had been free (in a sense of the word 'free' that even Catholics accepted). Thus the fairminded Cardinal Bellarmine felt safe in asserting that man 'absolutely considered' possesses liberum arbitrium, 'for the heretics do not contend about this matter, but only about man cast down from his condition through the sin of his first parent. ${ }^{38} \mathrm{He}$ also knew that many moderate Protestants believed that fallen human beings retain some liberty; unlike the Calvinists, Melancthon and Luther had once denied that human beings have freedom in what he referred to 'civil and external' affairs, but had afterwards retracted

35 John Bramhall, Castigations of Mr Hobbes his last animadversions (1658), pp. 281-2, quoting Institutes, 2.4.7. The quotation transposes 'liberam' and 'esse', but is otherwise completely accurate.

36 'Valeant igitur cum suo fato Stoici: nobis libera Dei voluntas sit moderatrix [?omnium]. Sed contingentiam tolli a mundo videtur absurdum (Ioannis Calvini opuscula omnia in unum volume collecta (Geneva, 1552), p.940).

37 Ibid. The acceptance of the two kinds of necessity was taken over, virtually unaltered, at Institutes, 1.16.9; the statement about the absurdity of Stoicism was not. $38 \quad$ Robertus Bellarminus, Disputationum...de controversiis Christianae fidei, adversus huius temporis hereticos, 4 vols. (Ingolstadt, 1601), vol.IV, col.690. 
their position. ${ }^{39}$ By the time that he was writing, however, some English Calvinists were demonstrably ready to make similar concessions.

One reason that this point have not been widely understood has been the understandable assumption that 'supralapsarian double predestination' - the belief that the decrees of reprobation and election were logically prior to God's knowledge of the Fall - implies divine determinism with respect to Adam. But the supralapsarian thinkers mentioned with respect by Hobbes - Theodore Beza ${ }^{40}$ and his English populariser William Perkins - in fact avoided drawing this conclusion. As the greatest living scholar of these matters has explained, 'both Beza and Perkins assume...a category of divine permission, and the existence, as well, of contingent events and freedom in the world. There is not even a tendency to metaphysical determinism... ${ }^{41}$ Analysis of what Perkins wrote strongly supports this verdict. Perkins refused to palliate the basic principle that the divine decree of reprobation 'ariseth of God's good meere good pleasure, no respect had of good or evill in the creature. ${ }^{42}$ But his discussion of the fall of Adam did not assert that Adam's freedom was compatible with the necessity imposed upon it. He retreated to a baffled string of reverent negations: 'we must not thinke that man's fall was either by chance, or God not knowing it, or barely winking at it, or by his bare permission, or against his will, but rather miraculously, not against the will of God, but yet without all approbation of it. ${ }^{43}$ The 'hardening' that Luther and Calvin had been reluctant to explain away was treated with conspicuous moderation: it involved a combination of 'permitting', 'occasioning' and 'disposing' (so ordering things that good comes out of evil); it did not involve specific direct action on the will. ${ }^{44}$ Though God imposed necessity upon the universe, he did so in a fashion that

doth not take away freedom in election, or the nature and property of second causes, but only brings them into certain order, that is, directeth them to certain order, that is, it directeth the[m] to the determinate end: whereupon the effects and events of thinges are contingent and necessary, as the nature of the second cause is. ${ }^{45}$

39 Bellarminus, Disputationes, IV, 714-17.

40 Beza is not mentioned in Questions, but his biblical commentaries are cited at Leviathan, II, 978 (where Hobbes is critical) and 1010 (where Hobbes is favourable).

$41 \quad$ Richard A.Muller, Post Reformation Reformedc Dogmatics: the rise and development of Reformed Orthodoxy, ca.1520-toca.1725 (Grand Rapids: Eerdmans, 2005), vol.I, p.128.

42 William Perkins, A Christian and plaine treatise of predestination (1606), tr.Francis Cacot and Thomas Tuke, p.25.

43 William Perkins, Golden chaine, sig.Cv.

$44 \quad$ Perkins, Predestination, 61-6.

$45 \quad$ Perkins, Golden chaine, sig. B2. 
In a work that began by stating common ground with Catholics, he held that 'we joyne with the papists' in asserting liberty 'even since the fall of Adam by a natural power of the mind.' This liberty extended to 'outward performance of civill and ecclesiasticall duties'. Perkins cautioned that 'man's will is weake and feeble, and his understanding dim and darke', and also that 'the will of man is under the will of God', but the dutiful qualifications confirm the principle that the human will is free in just the sense of the word 'free' that ordinary Catholics accepted. ${ }^{46}$

So far as we know, this position was quite conventional. No one had better Calvinist credentials than the rigorous supralapsarian William Twisse (later the prolocutor of the Westminster Assembly that would produce the Calvinistic Westminster Confession). But Twisse approvingly recalled that

In the time of my minority in the university [Twisse had matriculated in 1596, received his MA in 1604, and disputed for his BD in 1612], in divinity disputations we heard concerning free will such a distinction as this of common course. The actions of men are either natural or moral, or spiritual; the resolution of the truth, as touching free will, according to the foresaid distinction, was this; we have not lost our free will, in actions natural, nor in actions moral, but only in actions spiritual. ${ }^{47}$

Interestingly, Twisse pointed out that Calvinistic writers were actually more careful than some Augustinian Catholics to steer clear of deterministic language: 'to necessitate the will or determine the will are noe phrases of our Divines. ${ }^{48}$ Moreover, 'we know God is the first cause, and all other are but second causes in comparison to him. Yet we willingly confesse that the providence of God is wonderful and of a mysterious nature in this. ${ }^{49}$ It goes without saying that God determines everything that happens, 'but he moves every creature to work agreeably to its nature, necessary things necessarily, contingent things contingently, free Agents freely.' 50

\footnotetext{
46 William Perkins, A Reformed Catholike (1597), pp.11-13. For a very similar statement, again noting that free will exists but it is 'very weak', see William Perkins, $A$ golden chaine (1591), sig.C4+1.

$47 \quad$ William Twisse, The doctrine of the synod of Dort and Arles reduced to the practise. With a consideration thereof (1631) p .17.

48 Twisse, Riches of God's mercy (1653), Book II, p.74

49 Twisse, Riches, II, 75.

50 Twisse, Riches, II, 80. Most points made in this paragraph are actually undisputed;

Martinich quotes similar statements. But Martinich's view appears to be (i) that predestination of this type can be equated with 'determinism' with respect to God and (ii) that
} 
The church's official pronouncements were equally cautious. The canons of the synod of Dort concede that 'there are still in lapsed man some remains of the light of nature', implying not just some knowledge of 'the difference between good and evill', but even 'some care (studium) of virtue and of outward discipline'. Needless to say, 'hee doth not make right use thereof in civill and natural affairs: nay, that which it is, he many ways defileth it'. ${ }^{51}$ But the careful qualifications do not by any means exclude - and arguably imply - some traces of survival of Adamic liberty. The English delegation went much further, stating baldly that 'it is in every man's power to rule his moving faculty; and experience proves it, because we see, in outward things, men, as they will themselves, do this or that, or omit both. ${ }^{52}$ In the absence of qualifications, the commonsensical tone of the appeal to 'experience' seems to demand a libertarian reading. But here as elsewhere, the decisive point is the presence of the notion that men enjoy more freedom in some spheres of life than others and that the level of their freedom varies. Even at the high-water-mark of English Calvinism, there seems to be no evidence that any of its leaders were in a modern sense deterministic.

English Calvinists were in the modern sense compatibilist (Martinich, 'On Hobbes's English Calvinism', 24-5)

$51 \quad$ The judgement of the synod holden at Dort (1619), p.33.

52 The collegiat suffrage of the divines of Great Britaine (1629), p.68. 
My argument so far has been that mainstream Calvinism was not deterministic - even with respect to God - and that suggestions that it was were typically made by outsiders. There is good reason to believe that Hobbes was just such an outsider. But there is also one suggestive detail that might be thought to point in a quite different direction. Hobbes spent five years at Magdalen Hall in Oxford (from 1602 or 3 to February 1608). As an undergraduate studying the Arts course, he had, of course, no formal academic obligation to take an interest in theology; nor can it be assumed that theological instruction would have said much about predestination. The great theologian Richard Field (1561-1616), who had delivered well-regarded 'catechism lectures' at Magdalen Hall in the early 1590s, is said to have disapproved of disputations on the subject. ${ }^{53}$ But from 1605 onwards, the Hall was controlled by John Wilkinson, an ardent Calvinist who had or developed an interest in doctrinal education; William Pemble's Vindiciae fidei (1625) - a clear and forceful statement of the Calvinist understanding of the theology of justification - was written, at Wilkinson's request, as a Magdalen Hall lecture series. ${ }^{54}$ As Wilkinson recommended Hobbes for the attractive post of tutor and companion to a rich nobleman, it is unlikely that he doubted Hobbes's orthodoxy. ${ }^{55}$ It is, however, clear that Hobbes's Oxford education had not included anything resembling Pemble's lectures; in the absence of an open challenge to the Reformed position, perhaps no such instruction was considered necessary. ${ }^{56}$ If Hobbes had been grounded in orthodox Calvinist doctrine, he would, for example, have realised that his view of human 'merit' resembled the traditional Roman Catholic position. ${ }^{57}$

In any case, his early works yield little evidence that he identified with Calvinism. In a 1630 letter from Geneva, he praised a minister as 'a very wise and honest man and not of the

$53 \quad$ Nathaniel Field, Some short memorials of the Life of that reverend divine Richard Field (1717), pp.4, 21-2.

$54 \quad$ Pemble died young (at 29) in 1623 . The lectures were probably written in the early 1620s.

55 Thomas Hobbes, Thomae Hobbesii Malmesburiensis Vita (1679), p.3. In the prose autobiography, Hobbes says he was recommended by 'amici'; the plural suggests that Wilkinson was advised by some third parties (Thomae Hobbes Angli Philosophi Vita (1681), p.1).

56 According to Nicholas Tyacke, open anti-Calvinism did not emerge in Oxford before 1607, that is, Hobbes's final year in residence (Tyacke, Anti-Calvinists, pp.62-3).

57 William Pemble, Vindiciae fidei (1625), pp.230-1. 
Geneva print, more then is necessary for an inhabitant and minister in that place. ${ }^{58}$ Perhaps the expression 'the Geneva print' refers primarily to social and political attitudes as opposed to fundamental theological commitments, but it does seem to suggest a certain detachment. His later works suggested that he saw 'the Calvinists' as upholders of a basically scientific thesis. In The elements of law (1640), he wrote that 'this whole controversy, concerning the predestination of God, and the free-will of man, is not peculiar to Christian men', supporting this claim by referring, suspiciously vaguely, to 'huge volumes of this subject, under the name of fate and contingency, disputed between the Epicureans and the Stoics. ${ }^{59}$ The same detachment is observable in the 'Objections' he produced to Descartes' Meditations (1641), where he questioned the philosopher's conventional remark that 'I observe my errors to depend on two concurrent causes, that is, the faculty of coming to know that is in me and the faculty of choosing (facultas eligendi) or freedom of the will (arbitrii libertas)'. Hobbes noted that 'arbitrii libertas is assumed without proof, against the opinion of the Calvinists'. ${ }^{60}$

If we turn to his first expression of his own philosophy - the so-called 'Short Tract on First Principles ${ }^{61}$ - we find that his determinism developed very early, but that his line of argument involved no reference to theological considerations. In the thirteenth and fourteenth 'Principles' of the Short Tract's Section One, he set out definitions that his later works adhered to

12. Necessary is that which cannot be otherwise.

13. A Necessary cause, is that which cannot but produce the effect.

14. A sufficient cause is that, which hath all things requisite to produce the effect. $^{62}$

$58 \quad$ Hobbes, The correspondence, ed. Noel Malcolm, 2 vols (Oxford, 1994), vol.I, p.10.

$59 \quad$ El., II vi 9. Cf. De Cive, xviii 14.

$60 \quad$ Oeuvres de Descartes (Adam \& Tannery), VII, 190.

61 The argument presented here would not be much affected if, as many think, the Short Tract is actually a work by Hobbes's close friend Robert Payne. It is common ground that the impressive verbal and substantive parallels between the Tract and Hobbes's later writings include his accounts of 'necessary' and 'sufficient' causes, as well as the transition to asserting that the Molinist definition of a 'Free Agent...implies a contradiction'. If the author was Payne, he must either have borrowed these ideas or else (which seems fantastic), devised a deep, original, and dangerously heterodox theory, then somehow induced Hobbes to take it over. In other words, the argument - and perhaps its words - is surely Hobbesian, even if the Short Tract as a whole was written by another. For the parallels, see Karl Schuhmann, 'Le Short Tract, première oeuvre philosophique de Hobbes' in Schuhmann, Selected papers on renaissance philosophy and Thomas Hobbes, ed. P.Steenbakkers and C. Leijenhorst (Dordrecht: Kluwer, 2004), pp.239-40; for an acknowledgement of their force, see Noel Malcolm, Aspects of Hobbes (Oxford: Clarendon Press, 2002), pp.128-9.

62 British Library, Harley MS 6796, fo.297 
In the eleventh 'Conclusion' of that Section, he deduced that 'A Sufficient Cause is a Necessary Cause' on the grounds that

That Cause which cannot but produce the effect, is a Necessary Cause (by the 13 . Prin:) but a sufficient cause cannot but produce the effect. because it hath all things requisite to produce it (by the 14. Prin:) For if it produces it not, somewhat els is wanting to the production of it, and so the cause is not a sufficient cause, which is contrary to the supposition.

Corollary.

Hence appeares that the definition of a Free Agent, to be that Which, all things requisite to worke being putt, may worke, or not worke, implyes a Contradiction. ${ }^{63}$

In an implicit rejection of the necessitas consequentiae/necessitas consequentis distinction, he went on to maintain (in Conclusion 14) that 'Necessity hath no degrees', on the grounds that 'that that which is necessary is impossible to be otherwise (by the 12. Prin.) and that which is impossible is Non-Ens; and one Non-Ens cannot be more Non-Ens than another.' ${ }^{64}$ This argument is of interest because it seems to show that he was already committed to the extreme position that all events are 'necessary' or 'impossible' (as in his later writings, nonentity maps onto non-possibility). ${ }^{65}$ It goes well beyond the thinking of Calvin and Perkins, both of whom went out of their way to leave space for possibility: as Calvin explained, 'that which God has determined, though it must come to pass, is not, however, precisely or in its own nature necessary'. A prophecy made it certain that Christ's bones would not be broken, but it would still make sense to say that they were breakable. ${ }^{66}$

The Short Tract's discussion is nothing if not compressed. It is long enough, however, to identify the source by which his thinking on these points was structured. The definition of a 'Free Agent' that he criticised is a word-for-word translation of the definition offered in two widely-read works by the Jesuit Francesco Suarez: Disputationes Metaphysicae (1597) and 'De concursu, motione, et auxiliis Dei' (the latter printed in successive editions of Varia

63 Short Tract $\$ 1$ conc. 11 . The words printed in italics are written in a fractionally larger lettering presumably mean to signal a quotation.

64 Short Tract $\$ 1$ conc. 14 .

65 De Corpore, $\mathrm{x}$ 4; Thomas Hobbes, Critique du De Mundo de Thomas White, ed.Jean Jacquot and Harold Whitmore Jones (Paris: Vrin, 1973), xxxvii 5, 11.

66 Calvin, Institutes, 1.16.9 
Opuscula Theologica (1600)). ${ }^{67}$ The Short Tract's understanding was shaped by the former, which is a work of secular metaphysics (at least in the sense that its argument is said not to rely on premises disclosed by revelation). At some point, however, Hobbes also acquired some knowledge of the latter, which was a theological discussion of the relationship between the Catholic Christian God and human liberum arbitrium. ${ }^{68}$

In his capacity as a metaphysician, Suarez contrasted 'causes necessarily acting, if all things requisite to action are present' and 'causes that work without necessity and with liberty. ${ }^{69}$ For Suarez a 'cause' was an 'agent', and 'things requisite to action' included the proximity of another entity with characteristics requisite to being acted on. A cause necessarily acting would invariably act when brought into proximity with a suitably-disposed patient. There were, however, agents that could refrain from acting even in such conditions. Suarez gave Hobbes the germ of an important argument by admitting that a cause that worked without necessity would require a 'faculty or power that has the strength to restrain its own working (vim continendi operationem suam), even when all things requisite to working have been put' ${ }^{70}$ In the Short Tract, Hobbes accepted the essentials of this theory: he too believed that agents work if and only if they are combined with 'patients' that are suitably located and appropriately disposed (although he insisted on contact, not just proximity). But he thought that a 'power to suspend' an act upon a patient would always operate unless it was itself suspended by a second-order power to suspend 'and so on in infinitum, which is absurd. ${ }^{, 71}$

The Suarezian framing of Hobbes's theory has large and interesting implications. For present purposes, though, its main importance is that the Hobbesian view of Protestant theology is noticeably Suarezian in character. In a full and helpful discussion of the possible range of senses of the liberty-necessity distinction, Suarez points out that if 'necessary' means 'involuntary', then liberty does not exclude

67 Metaphysical disputations, 19.4.4; 'De concursu Dei', Book I, chapter iii, paragraph 2 in Varia opuscula theologica (Moguntiae, 1600), p.13. On the relationship with Suarez, see Schuhmannn, 'Le Short Tract', 250-57. Suarez in turn drew his definition from Molina (Chappell, Hobbes and Bramhall, 39n). Pace Schuhmann (p.256), Hobbes's later admission that he did not know who invented it (AntiWhite, xxxiii 1) is not a sign that he had forgotten Suarez, but only that he was aware that many writers used this formulation..

$68 \quad$ Leviathan, 122; Questions, 9.

$69 \quad$ Metaphysical disputations, 19. 1 and 2.

$70 \quad$ Metaphysical disputations, 19.2.4.

$71 \quad$ ST $\S 1$ conclusion 8. 
determination to one with an incapacity of restraining action, but excludes only violence and coercion; in which sense it is evident that there are actions that are not necessary not only in human beings but also in brutes, although those actions are more completely free in human beings to the extent that the basis of the voluntary [which Suarez believed to be the intellect] is more completely found in them. On which grounds some, especially heretics, have taken occasion to say that human actions are free on no other grounds than that they are completely voluntary... ${ }^{72}$

It is obvious that the position ascribed to 'heretics' was also the position Hobbes adopted. Suarez seems not to have thought that all these heretics believed in physical determinism: he mentioned that 'some denied liberty in all actions, internal and external, good and bad, but others only in moral or worthy actions, but not in civil or indifferent ones. ${ }^{73}$ But on the one occasion that he referred to 'Calvin and his followers', he accused them of defending an outright fatalism in which necessity was imposed 'not only by the influence of the stars, but by the higher influence of God moving and setting to work all the second causes in such a way that they do by necessity that to which they are impelled and nothing else. ${ }^{74}$

The thinker who did most to shape the Hobbesian theory was thus a Roman Catholic who seems to have believed that Calvinism was determinist. It is not clear when, if ever, Hobbes obtained a first-hand knowledge of mainstream Protestant theology. There is, however, one passage of his critique of Thomas White (a work composed in 1642-43) suggesting he had read a little further. In that work, Hobbes notes that some people believe in an absolute power of doing or not doing, while others maintain (as he did) that liberty is simply power to do what one happens to will. But he also notes the existence of a third opinion: that 'men have liberum arbitrum ad malum in such a way that they can absolutely do or not do an evil that is presented to them, but not liberum arbitrium ad bonum. Moreover that men are in such a condition with respect to choice of the good that they are as it were dead.' In discussing this opinion, he objected, among other things, to the simile of death. ${ }^{75}$ In doing so, he was objecting to Calvinist language: William Perkins, for example, held 'that Man not regenerated hath free-will to do only that which is evill, none to do good', on the scriptural grounds that 'Man is not said to be weake, or sicke, but dead in sinne'. ${ }^{76}$ But Hobbes thought that this was the 'opinion of few men and one that perhaps furthers their other

72 Suarez, Metaphysical disputations, 19.2.9.

73 Suarez, Metaphysical disputations, 19.2.10.

74 Suarez, Metaphysical disputations, 19.11.3

$75 \quad$ AntiWhite, xxxvii 7.

76 Perkins, Golden chaine, 250. 
opinions. ${ }^{77}$ This baffled remark suggests that he had failed to recognise that this 'opinion of few men' was quite conventional. The same surprising ignorance affected his performance when he embarked on his debate with Bramhall.

III

The Hobbes-Bramhall debate was really not one but two debates. The first, which took place in 1645-46, was a three-part written exchange (Bramhall - Hobbes - Bramhall) arising from an earlier, oral discussion in the presence of their patron, the earl of Newcastle. ${ }^{78}$ As numerous features of his stance reveal, John Bramhall, the bishop of Derry, was an Arminian. There is no doubt, however, that his intellectual training had left him with a grasp of Calvinism. His Cambridge education had been received at Sidney Sussex College, a puritan foundation and a Calvinistic stronghold whose famous Master, Samuel Ward, attended the Synod of Dort. As we shall see, a striking feature of the episode was that a competent thinker with a background of this type was unaware of anyone who seriously defended Hobbes's extreme determinist position.

At Newcastle's suggestion, Bramhall drafted a brief paper that set out the case for 'free will' as he then understood it. One interesting point that emerges from this statement is that the opponents that Bramhall found it easiest to imagine were not, in any ordinary sense, determinist. They were people, to begin with, who objected to being called 'Stoic', unless their Stoicism was identified as 'Christian'. A Christian Stoic asserted 'that the Stoicks did take away liberty and contingence, but [we] admit it' and that 'in respect of the second causes many things are free, but in respect of the first cause all things are necessary. ${ }^{79}$ As later allusions confirm, ${ }^{80}$ his most important target here was Justus Lipsius, who made all the points attributed to these Christianised Stoics within a single chapter of his De Constantia. ${ }^{81}$

$77 \quad$ AntiWhite, xxxvii 7.

78 On the chronology and other circumstantial detail, see Nicholas Jackson, Hobbes, Bramhall and the politics of liberty and necessity: a quarrel of the civil wars and interregnum (Cambridge: Cambridge University Press, 2007).

79 Hobbes, Questions, 193

$80 \quad$ Hobbes, Questions, 195, 197; Bramhall, Castigations, 244.

81 Justus Lipsius, Two books of constancie, tr.Sir John Stradling, ed.Rudolf Kirk (New Brunswick, NJ: Rutgers University Press, 1939), pp.121-3. 
But the Lipsian position was an undemanding one; as Bramhall later remarked, Lipsius was 'no such friend of any sort of destiny, as to abandon the liberty of the will. The Stoics themselves came short of T.H. his universal necessity. ${ }^{82}$ The Lipsian text confirms this particular claim: Lipsius invoked traditional distinctions between necessitation and foreknowledge that Hobbes was subsequently to scorn as meaningless:

God by the power of destiny draweth al things, but taketh not away the peculiar facultie or motion of any thing. He would that trees and corn should grow. So do they, without any force of their own nature. Hee would that men should use deliberation and choyse. So do they, without force, of their free-will. For God that created all things useth the same without any corruption of them. And yet, whatsoever they were in mind to make choyse of, God foresaw from all eternitie: He foresaw it, I say, not forced it: hee knew it, but constrained not: he foretolde it, but not prescribed it. ${ }^{83}$

Some of Bramhall's other targets were, however, 'Calvinist'. From a Calvinist perspective, his most offensive view was his complete rejection of the legitimacy of the non-violent manipulation that Calvinists routinely attributed to God:

If a strong man holding the hand of a weaker, should therewith kill a third person, haec quidem vis est, this is violence, the weaker did not willingly perpetrate the fact, because he was compelled. But now suppose this strong man had the will of the weaker in his power as well as the hand, and should not onely incline, but determine it secretly and insensibly to commit this act, is not the case the same?

In a curious illustration of what he was trying to say, Bramhall compared the ravishing of Lucretia to the approach of someone who made subtle use of magic to incline her effectually, and draw her inevitably, and irresistibly to follow him spontaneously.' Both lines of conduct were deplorable,

but the latter person is more guilty, and deserves greater punishment, who endeavours also so much as in him lies, to make Lucretia irresistibly partake of his crime. I dare not apply it, but thus only: take; heed how we defend those secret and invincible necessitations to evil, though spontaneous and free from coaction. ${ }^{84}$

The obvious application of this general principle was that the Calvinists had made the Almighty the author of sin. But Bramhall's evident distaste for Calvinistic theories did not

82 Bramhall, Castigations, 244.

83 Lipsius, Constancie, 122.

$84 \quad$ Hobbes, Questions, 216. 
impel him to misrepresent them. He took it for granted that 'the greatest opposers of our liberty are as earnest maintainers of the liberty of Adam. ${ }^{, 85}$

In his reply to Bramhall, Hobbes crossed the territory of Calvinist/Arminian disagreements without, however, presenting himself as Calvinist. Moreover, he made an extraordinary tactical blunder that somebody familiar with Calvinist ideas might reasonably have hoped to have avoided. As Bramhall implied when speaking of Lucretia, Calvinists from Calvin onwards had used the word spontaneus in order to describe the freedom they contrasted with coercion. Calvin himself believed an action was spontaneous if it were not 'impelled by an external motion', in which case it could be counted as being 'voluntary'. ${ }^{86}$ On a page Hobbes later quoted in defence of his own view of freedom, the theologian Girolamo Zanchi (1516-1590) explained that 'the spontaneous is not opposed to the necessary, but to the violent'. Zanchi went on to argue that that human actions were spontaneous, even if they were impelled by an 'external principle', if they were also approved by an 'internal principle' (his example was somebody led by the hand to a banquet in his honour). ${ }^{87}$ But in Zanchi's view a falling stone could move spontaneously. ${ }^{88}$ Hobbes might have been expected, then, to appropriate the word by reserving it for cases in which the causal chain ran through a person's appetite, identifying the spontaneous with the 'voluntary'. But when he came to write about the word 'spontaneous', he opted instead to distinguish the two concepts, denying the term 'spontaneous' to actions performed out of fear (though he admitted that such acts were 'willing'), and denying the term 'voluntary' to actions that were done without some precedent deliberation. In doing so, he set off a fruitless wrangle in which he regretted the use of 'this strange word Spontaneous' and asked (rhetorically) 'Why did the School-men bring it in, if not meerly to shift off the difficulty of maintaining their tenet of Free-Will ${ }^{89}$. It seems to have escaped him that the use of the strange word was actually characteristic of the Calvinist position.

85 Hobbes, Questions, 80.

86 John Calvin, Defensio sanae et orthodoxae doctrinae de servitute ac liberatione humani arbitrii (Geneva, 1543), p.66.

87 'Neque spontaneum opponitur necessario, sed violento' (Hieronymi Zanchii

Tractationum theologicarum volumen (1603), p.117. The citation ('Tract Theol. Cap.6. Thes. 1') is found at Questions, 235.

88 Zanchi, Tractationes, 118. Bramhall, by contrast required 'an inward principle (that is the will) with some knowledge of the end' (Bramhall, Castigations, 74).

$89 \quad$ Hobbes, Questions, 69. 
Hobbes's self-presentation in this first phase of debate thus tells against the theory that he was motivated by any real Calvinist commitment. In the later phase, however, some reference to the Calvinist/Arminian disputes was practically unavoidable. The occasion of the later publications was the emergence into print of Hobbes's little treatise (without the piece by Bramhall to which it was an answer). To make things worse, the book was given a shrill anticlerical preface (which was clearly not by Hobbes) and the misleading title: $O f$ liberty and necessity a treatise, wherein all controversie concerning predestination, election, merits, free-will, grace, merits, reprobation \&c is fully cleared, in answer to a treatise written by the Bishop of London-derry on the same subject (1654). At this point, Bramhall published $A$ defence of true liberty from ante-cedent and extrinsecall necessity (1655), which reproduced all three of the earlier treatises with a very brief explanatory preface. Beyond deploring the ridiculous title, he made no attempt to divert the debate to discuss theological questions. It was Hobbes's riposte (the fourth of the five contributions), The questions concerning liberty, necessity, and chance (1656), that first connected Hobbesian ideas and Calvinism, in doing so giving Arminians an opportunity to tar their enemies with the brush of Hobbist heresy.

One passage in The Questions is particularly important. Hobbes was contesting Bramhall's claim that 'he who doth necessitate the Wil to evil is the cause of evil', by which, Hobbes said, 'he thinks he shall force me to say that God is the cause of sin'. ${ }^{90}$ He commented that 'to use so unseemly a Phrase as to say that God is the cause of sin, because it soundeth so like to saying that God sinneth, I can never be forced by so weak an argument as this of his. ${ }^{91} \mathrm{He}$ then went on to quote six Protestant sources who shared his view that liberty, though it excludes 'constraint', is quite consistent with 'necessity'. He went on to remark that 'all the famous Doctors of the Reformed Churches, and with them St Augustine are of the same opinion. None of these denied that God is the source of al Motion \& Action, or that God is the cause of al Lawes, and yet they were never forced to say that God is the cause of sin. ${ }^{92}$ Hobbes was on firm ground here. It is, however, worth noting that he was arguing ad hominem: he was arguing that thinkers that Bramhall had a duty to respect had not been obliged by the premise that Bramhall criticised to 'say' something 'so like to' the statement that 'God sinneth'. The Latin version of Leviathan actually mocks the claim that God is not

$91 \quad$ Hobbes, Questions, 235.

92 Hobbes, Questions, 234-5. 
the 'cause' of sin, while agreeing with the Calvinists that God is not its 'author'. ${ }^{93}$ He was borrowing one feature of a theology with which he had virtually nothing else in common.

When they were faced with Hobbes's appeal to Calvinism, Arminians had a choice between two possible responses. The first to emerge, by Thomas Pierce, made use of Hobbes's statements to attack the Calvinists. He set out to insinuate that Hobbesian ideas had close affinities with Calvinism: 'I have many reflections on Mr Hobbs, because he jumps so often with my assailants. ${ }^{94}$ This line of attack had potential, but the Hobbesian-Calvinist fusion it suggested was really a polemical Arminian construction. Bramhall's approach was different and perhaps more damaging. It seems to have been The Questions that made him realise how little Hobbes knew about Calvinism, at least as it was understood in academic circles. In his final contribution, this ignorance in itself became one of his major targets. Bramhall's answer to The Questions, his vigorous Castigations of Mr Hobbes his last animadversions (1658), is amongst other things a defence of the whole enterprise of university theology. His defence of scholastic learning was ecumenical: Hobbes was unfair to Catholics 'as if they exemted the will of man from the dominion of God's will'; ${ }^{95}$ he was unfair to the Reformed in holding that their positions were deterministic. As an Arminian, he had an obvious interest in claiming (like Pierce) that Calvinists were really Hobbesian. But he opted not to do so. Hobbes had professed himself puzzled by Bramhall's statement that 'the conversion of a sinner concerns not the Question'. ${ }^{96}$ Bramhall commented that

He saith, 'He understands not these words' [the conversion of a sinner concernes not the question]. I do really believe him... Let him study better what is the different power of the will, in naturall or civill actions, which is the subject of our discourse, and morall or supernaturall acts, which concern not this question; and the necessity of adding those words will clearly appear to him. ${ }^{97}$

93 Hobbes, Lev., II 1093. In Martinich's helpful essay, 'L'auteur du péché et les démoniaques' in Jean Calvin et Thomas Hobbes: naissance de la modernité politique, ed.Oliver Abel, Pierre-Francois Moreau, and Dominique Weber (2013), he notes that Hobbes was critical of the Calvinist position that God can cause the action without also causing the sin (p.50), but sees Hobbes's position on the authorship of sin as an argument defending Calvinism. Hobbes offers three arguments (53-4), two which were certainly also used by Calvinists. What is non-Calvinist about his thinking is that these arguments omit a reference to 'freedom'. Hobbesian freedom (absence of obstruction) has no conceivable bearing on the question.

94 Thomas Pierce, Autokatakrisis, or self-condemnation exemplified (1658), 'To the reader'.

$95 \quad$ Bramhall, Castigations, 4.

96 Hobbes, Questions, 3.

$97 \quad$ Bramhall, Castigations, 7. See also pp.30 and 69. 
At this point, of course, one should pause. Many modern accounts of pre-modern theological debates reproduce the most tiresome feature of their material: its tendency to endless selective proof-texting. It was only to be expected that a rather hasty reading of some rather abstract works that tried to hold apparently conflicting truths in tension should yield a hasty reader the results he was expecting: these works undoubtedly contain a plethora of statements that seem, in isolation, to be determinist. Moreover, it was a feature of the Hobbesian position that he agreed that 'Men are Free to Do as they Will, and to Forbear as they Will'; 98 his objection was to language involving a regress in which it was the will that did the willing. But it is difficult to see how a philosopher who was in some sense motivated by his 'Calvinism' could have been, and remained, so ignorant of the libertarian side of books that he was anxious to imply that he had read. For example, he was happy to excerpt the (mis)quotation 'Witness the devils who are necessarily wicked, and yet sin freely without constraint' from the conclusion of the following passage:

We intend not to take from corrupt and unregenerate man all freedom of the will: we know well that in natural actions, which are ruled by the will, as to eat and to go, man freely chooseth among many objects...we say more that man hath his free will in good and honest actions, belonging to civill honesty: as the actions of pagans, which help a man up who has fallen down...And which is more, we say that a man sinneth very freely, and without constraint, and between two evils chooseth very freely. And this is the same liberty which imposeth on him the necessity to sinne, because he is naturally subject to sinne, naturally evill. Therein consists his mischief, that he is too free to do evill, so that his freedom is the cause of his servitude. Witness the devils, which are naturally and necessarily wicked, and yet sin most freely and without constraint ... ${ }^{99}$

Even if all this language about freedom is taken to refer to merely Hobbesian liberty - the freedom to do what one wills - it remains the case that whether or not an act is free depends upon the sphere that it belongs to. Either Hobbes was uninstructed in some fairly basic features of actual Jacobean orthodoxy or his contempt for it was so complete that he cared little how he tortured it. In either case, his radically deterministic vision was not, in any important sense, the fruit of Calvinism.

98 Hobbes, Questions, sig.a.

99 Peter du Moulin, The buckler of faith (1620), pp.81-2. This work was first published in French as Le bouclier du foi, but Hobbes quotes the title in English. 
This chapter's main conclusions have been rather negative; it seems worth emphasising they are also limited. If the arguments brought forward are basically sound, they show that his opinions about necessity and liberty were neither derived from early doctrinal instruction nor from a subsequent study of the writers he referred to. It is, however, possible that there were Calvinists who were becoming open to deterministic views. The example well known to Hobbes scholars is Edward Bagshaw, an erratic young man of unquestionable Calvinist credentials who wrote to Hobbes requesting clarification about the question of divine foreknowledge. ${ }^{100}$ It is at least imaginable that somebody who started from a Calvinist position might have been driven by interest in mechanistic physics towards a Hobbesian determinism resembling, perhaps, the ideas of Jonathan Edwards. ${ }^{101}$

As we have seen, however, it is implausible that someone who knew as little as Hobbes about elementary details of Calvinist ideas of justification could possibly have had a Calvinistic starting point. This raises an interesting question. If 'Calvinism' was irrelevant - and if determinism was virtually unknown - it is natural to wonder what features of his outlook could possibly have motivated his extreme position. The conventional explanation is that he was responding to the works of Galileo, but it was possible to admire the recent advances in physics without feeling driven to such extreme conclusions. Moreover, his convictions were developed very early. As we have seen, the Short Tract includes the argument that 'that, which is impossible is Non-Ens; and one Non-Ens cannot be more Non-Ens than another', implying, against Suarez, ${ }^{102}$ that events are either necessary or impossible. ${ }^{103}$ It is, then, worth considering another explanation in which religious feeling plays a more significant role.

It goes without saying one pressure on Hobbes comes from 'Philosophy', a discourse (as Bramhall complained) ${ }^{104}$ which is shaped by what can be 'imagined'. For Hobbes, imagination deals with bodies and their motions. It thus excludes theology, which deals with the 'doctrine of God, eternal, ingenerable, incomprehensible and in whom there is nothing to divide nor compound, nor any generation to be conceived'. ${ }^{105}$ A major unsolved problem facing Hobbes scholarship is the precise relationship between Philosophy (which must have

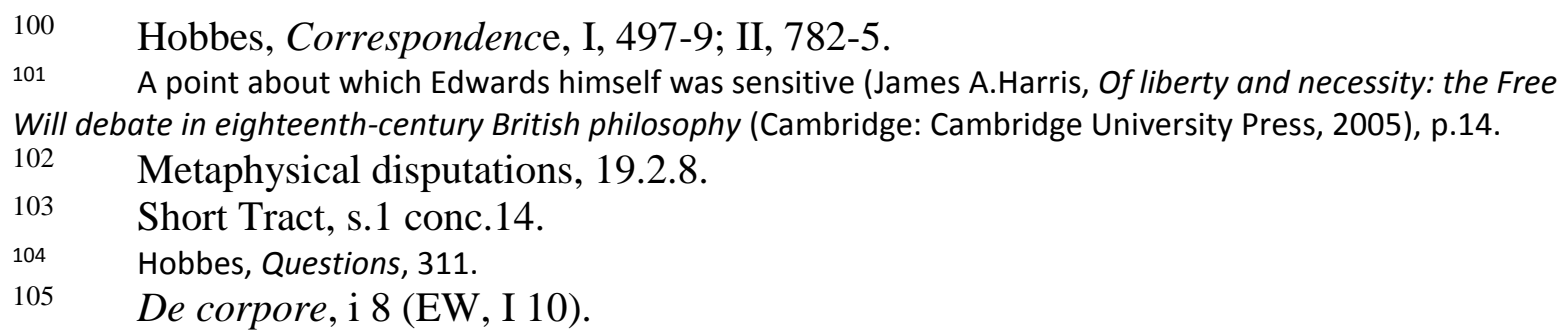


meaning) and talk about God (which is really worship: that is, which gives expression to opinions of his power). ${ }^{106}$ The boundaries of Philosophy are surprisingly extensive: as we have seen, both 'free will' and the eucharistic presence are thought to fall within its jurisdiction. So, much more questionably, is the question of God's 'foreknowledge', which cannot, Hobbes alleges, be merely 'intuitive', that is, divorced from physical causation. ${ }^{107}$

Foreknowledge lay at the heart of an extremely revealing exchange arising from one of Bramhall's strongest debating points. Bramhall acutely stated that 'he will not deny, but if it had been the good pleasure of God, he might have made some causes free from necessity, seeing that it neither argues any imperfection, nor implies a contradiction.' 108 Hobbes tacitly conceded this involves no contradiction, but replied 'that if God had made either causes or effects free from necessity, he had made them free from his own Praescience, which had been imperfection.' 109 There are two ideas at work here: one, which is philosophical, is an analysis of prescience that utterly refuses to divorce it from causation; the other, which is religious, is that God would be 'imperfect' if (as He might do) He released control.

It was the interaction between these two ideas that gave Hobbes's determinism plausibility. The latter was admittedly a Calvinist idea (this is the constructive truth within the Calvinism thesis), but there was no need to derive it from Calvinist sources: all Calvinists were determined to uphold God's sovereignty, but so, in their own sense, were virtually all Christians. As Bramhall had said, 'you wrong the Doctors of the Roman of the Roman Church as if they exemted the will of man from the dominion of God's will' ${ }^{110}$ Without abandoning the claim that God is in control, the Augustinian paradigm that still shaped Calvinism had the resources to describe a textured universe in which liberum arbitrium played an essential role in giving God just enough distance from his creatures' sinful actions. But Hobbesian philosophy did away with those resources. Within his flattened universe, imagined as bodies in motion, the physical 'concourse of causes' is the 'decree of God'.111 The God-free agent nexus is in all respects the same as God's connection with all other unobstructed motions. Somebody who thinks of the world in this way is bound to be affronted by 'the Doctrine of Free-Will', understood (as it must be within this radically

\footnotetext{
$106 \quad$ Leviathan, 560.

107 Hobbes, Questions, 346

108 Hobbes, Questions, 320.

109 Hobbes, Questions, 325-6.

110 Bramhall, Castigations, 4.

111 Hobbes, Questions, 80.
} 
simplified system) as 'a Will of man, not subject to the Will of God.'112 It was quite understandable that Hobbes should have scorned as evasions both the concept of permission and the idea that God can cause the act but not the $\sin .{ }^{113}$ The point he did not grasp was that these Arminian evasions were actually evasions that were shared with Calvinists.

It is, however, important that this biographical finding about Hobbes's Calvinism does not decide the question about his theism. Commitment to God's omnipotence is a religious impulse. If near the heart of Hobbes's thought was a religious vision requiring that God have the same kind of necessary relation to every event and action within the universe, it would explain how he arrived at his determinism at such an early moment of his development - and why he was so loyal to what his contemporaries in general regarded as a ludicrous position. If it was religious excitement that played at least some role in shaping Hobbes's theory, there would also be a further, more political implication: the proper response - 'honour' - to divine omnipotence would surely include individual and collective acts of worship.

\footnotetext{
112 Lev., II 1090

113 Hobbes, Questions, 89.
} 